\title{
Effect of Steel Fibres and Low Calcium Fly Ash on Mechanical and Elastic Properties of Geopolymer Concrete Composites
}

\author{
Atteshamuddin S. Sayyad and Subhash V. Patankar \\ Department of Civil Engineering, SRES's College of Engineering, Kopargaon, Maharashtra 423601, India \\ Correspondence should be addressed to Atteshamuddin S. Sayyad; attu_sayyad@yahoo.co.in
}

Received 17 August 2013; Accepted 7 November 2013

Academic Editors: D. Gomez-Garcia, F. M. Morales, A. Simar, and S. Thomas

Copyright (c) 2013 A. S. Sayyad and S. V. Patankar. This is an open access article distributed under the Creative Commons Attribution License, which permits unrestricted use, distribution, and reproduction in any medium, provided the original work is properly cited.

\begin{abstract}
Effect of steel fibres and low calcium fly ash on mechanical and elastic properties of geopolymer concrete composites (GPCC) has been presented. The study analyses the impact of steel fibres and low calcium fly ash on the compressive, flexural, split-tensile, and bond strengths of hardened GPCC. Geopolymer concrete mixes were prepared using low calcium fly ash and activated by alkaline solutions $\left(\mathrm{NaOH}\right.$ and $\left.\mathrm{Na}_{2} \mathrm{SiO}_{3}\right)$ with solution to fly ash ratio of 0.35 . Crimped steel fibres having aspect ratio of 50 with volume fraction of $0.0 \%$ to $0.5 \%$ at an interval of $0.1 \%$ by mass of normal geopolymer concrete are used. The entire tests were carried out according to test procedures given by the Indian standards wherever applicable. The inclusion of steel fibre showed the excellent improvement in the mechanical properties of fly ash based geopolymer concrete. Elastic properties of geopolymer concrete composites are also determined by various methods available in the literature and compared with each other.
\end{abstract}

\section{Introduction}

Plain cement concrete suffers from numerous drawbacks such as low tensile strength, brittleness, unstable crack propagation, and low fracture resistance. Addition of steel fibres in plain cement concrete improves its mechanical and elastic properties. Hence, steel fibre reinforced concrete has been proved as a reliable and promising composite construction material having superior performance characteristics compared to conventional concrete.

The rate of production of carbon dioxide released to the atmosphere is increasing due to the increased use of Portland cement in the construction. Each ton of Portland cement releases a ton of carbon dioxide into the atmosphere. The greenhouse gas emission from the production of Portland cement is about 1.35 billion tons annually, which is about $7 \%$ of the total greenhouse gas emissions. On the other side, fly ash is the waste material of coal based thermal power plant available abundantly but this poses disposal problem. Several hectares of valuable land are acquired by thermal power plants for the disposal of fly ash. With silicon and aluminium as the main constituents, fly ash has great potential as a cement replacing material in concrete. The concrete made with such industrial wastes is eco-friendly. Although the use of Portland cement is still unavoidable, many efforts are being made in order to reduce the use of Portland cement in concrete. Davidovits [2] have invented a new technology called geopolymer, in which cement is totally replaced by fly ash (Pozzolanic material) and activated by alkaline solution. It is found that geopolymerisation can make a profitable contribution towards recycling and utilization of waste materials such as fly ash. This technology is, however, still fairly unknown and predictably viewed with skepticism by most workers in the field of traditional waste processing techniques [2-4].

Chindaprasirt et al. [5] studied the workability and strength of coarse high calcium fly ash geopolymer concrete. Rangan [6] have proposed the mix design procedure for production of fly ash based geopolymer concrete, whereas Anuradha et al. [7] have presented modified guidelines for mix design of geopolymer concrete using Indian standard. Patankar et al. [8] studied the effect of sodium hydroxide on flow and strength of fly ash based geopolymer mortar. Theory and applications about the potential use of geopolymeric 
TABLE 1: Chemical composition of fly ash.

\begin{tabular}{lccccccccc}
\hline Chemical composition & $\mathrm{SiO}_{2}$ & $\mathrm{Al}_{2} \mathrm{O}_{3}$ & $\mathrm{Fe}_{2} \mathrm{O}_{3}$ & $\mathrm{MgO}$ & $\mathrm{SO}_{3}$ & $\mathrm{Na}_{2} \mathrm{O}$ & $\mathrm{CaO}$ & $\begin{array}{c}\text { Total } \\
\text { chlorides }\end{array}$ & $\begin{array}{c}\text { Loss of } \\
\text { ignition }\end{array}$ \\
\hline Percentage (\%) & 77.10 & 17.71 & 1.21 & 0.90 & 2.20 & 0.80 & 0.62 & 0.03 & 0.87 \\
\hline
\end{tabular}

materials to immoblise toxic metals have been presented by Van Jaarsveld et al. [9]. Effect of recycled concrete aggregate on various strengths of geopolymer concrete has been studied by Anuar et al. [10]. Alonso and Palomo [11] have used metakolin as a substitute for the fly ash to study the effect of temperature and activator concentration on geopolymer concrete. Sumajouw et al. [12] have carried out a study on slender reinforced columns using fly ash-based geopolymer concrete. Bakharev [13] studied the resistance of geopolymer material to acid attack, whereas Pernica et al. [14] studied the effect of test condition on the bending strength of a geopolymer reinforced composite. Vijai et al. [15-17] has studied effect of glass fibres and steel fibres on various strengths of geopolymer concrete. Sathish Kumar et al. [18] also studied the properties of glass fibre reinforced geopolymer concrete. Bhowmick and Ghosh [19] studied the effect of synthesizing parameters on workability and compressive strength of fly ash based geopolymer mortar. Ghugal and Bhalchandra [20] studied the effect of steel fibre on mechanical and elastic properties of high strength silica fume concrete.

In the present study, an experimental investigation on mechanical and elastic properties of low calcium fly ash based GPCC has been carried out. Geopolymer concrete mixes were prepared with solution to fly ash ratio of 0.35 . Crimped steel fibres having aspect ratio of 50 are used.

\section{Experimental Programme}

Experimental work is designed to study the effect of steel fibres on mechanical and elastic properties on geopolymer concrete. The materials used for making fly ash geopolymer concrete composite specimens are low-calcium fly ash, course and fine aggregates, steel fibres, alkaline solution, and water.

2.1. Fly Ash. Fly ash is the residue from the combustion of pulverized coal collected by mechanical or electrostatic separators from the flue gases of thermal power plants. One of the important characteristics of fly ash is the spherical form of the particles. This shape of particle improves the flow ability and reduces the water demand. In this experimental work, the fly ash used is obtained from the silos of Eklahare Thermal Power Station, Nasik, Maharashtra, India, which is of low calcium, Class F (American Society for Testing and Materials). The fly ash which contains less than $10 \%$ calcium oxide is called Class $\mathrm{F}$ or low calcium fly ash. It is mainly pozzolanic and reacts with calcium hydroxide formed during the hydration process in moist condition to produce cementitious compounds when used with cement. Low calcium fly ash makes substantial contributions to the workability, chemical resistance, and reduction in thermal cracking. Table 1 shows the chemical composition of fly ash used for the experimental investigation.
TABLE 2: Chemical composition of sodium hydroxide and sodium silicate.

\begin{tabular}{|c|c|c|c|}
\hline \multicolumn{4}{|c|}{ Chemical composition } \\
\hline Sodium hydroxide & $\begin{array}{c}\text { Percentage } \\
(\%)\end{array}$ & Sodium silicate & $\begin{array}{c}\text { Percentage } \\
\text { (\%) }\end{array}$ \\
\hline $\begin{array}{l}\text { Sodium hydroxide } \\
\text { (min. assay) }\end{array}$ & 97 & $\mathrm{Na}_{2} \mathrm{O}$ & 16.37 \\
\hline Carbonate & 2 & $\mathrm{SiO}_{2}$ & 34.31 \\
\hline Chloride & 0.01 & Total solid & 50.68 \\
\hline Sulphate & 0.05 & Water content & 49.32 \\
\hline Potassium & 0.1 & - & \\
\hline Silicate & 0.05 & - & \\
\hline Zinc & 0.02 & - & \\
\hline
\end{tabular}

TABLe 3: Properties of aggregates.

\begin{tabular}{|c|c|c|c|}
\hline \multirow{2}{*}{$\begin{array}{l}\text { Physical } \\
\text { properties }\end{array}$} & \multicolumn{2}{|c|}{ Coarse aggregate (CA) } & \multirow{2}{*}{$\begin{array}{c}\text { Fine aggregate } \\
(\mathrm{FA})\end{array}$} \\
\hline & CA-I & CA-II & \\
\hline Type & Crushed & Crushed & River sand \\
\hline Maximum size & $20 \mathrm{~mm}$ & $12.5 \mathrm{~mm}$ & $4.75 \mathrm{~mm}$ \\
\hline Specific gravity & 2.641 & 2.639 & 2.563 \\
\hline $\begin{array}{l}\text { Water } \\
\text { absorption }\end{array}$ & $0.59 \%$ & $0.82 \%$ & $1.56 \%$ \\
\hline $\begin{array}{l}\text { Moisture } \\
\text { content }\end{array}$ & Nil & Nil & Nil \\
\hline
\end{tabular}

2.2. Alkaline Solution. The laboratory grade sodium hydroxide $(\mathrm{NaOH})$ in flake form and sodium silicate $\left(\mathrm{Na}_{2} \mathrm{SiO}_{3}\right)$ solution were used as alkaline activators. The chemical compositions of both activators are given in Table 2. Concentration of $\mathrm{NaOH}$ is fixed at $13 \mathrm{M}$ as per a previous research [8].

2.3. Aggregates. Locally available river sand is used as a fine aggregate (FA) and crushed basalt stones of nominal maximum size of $20 \mathrm{~mm}$ and $12.5 \mathrm{~mm}$ are used as coarse aggregates (CA). The physical properties of CA and FA are shown in Table 3 whereas Table 4 shows grading of CA.

2.4. Steel Fibres. Crimped steel fibres with aspect ratio $\left(L_{f} / h_{f}\right) 50$ is used with modulus of elasticity $(E)$ of $210 \mathrm{GPa}$.

2.5. Mix Proportion of Geopolymer Concrete. Fly ash, coarse aggregates, fine aggregate, and steel fibres are initially mixed together in dry state and then the liquid component of the mixture is added to prepare wet mix until it gives homogeneous mix. Mix proportion and fibre quantity of geopolymer concrete per cubic meter are given in Tables 5 and 6 respectively. 
TABLE 4: Grading of course aggregates.

\begin{tabular}{lccccc}
\hline $\begin{array}{l}\text { Serial } \\
\text { number }\end{array}$ & IS Sieve size $(\mathrm{mm})$ & CA-I & $\begin{array}{c}\text { CA-II } \\
12.5 \mathrm{~mm}\end{array}$ & $\begin{array}{c}\text { CA-I : CA-II } \\
65: 35\end{array}$ & $\begin{array}{c}\text { Required grading as per } \\
\text { IS 383-1970 }\end{array}$ \\
\hline 1 & $20 \mathrm{~mm}$ & 100 & 100 & 100 & 100 \\
2 & 25 & 100 & 100 & 100 & - \\
3 & 20 & 90.60 & 100 & 93.89 & -100 \\
4 & 16 & 6.80 & 100 & 39.42 & - \\
5 & 12.5 & 0.40 & 96.5 & 34.04 & $25-35$ \\
6 & 10 & 0.00 & 76.4 & 26.74 & $0-10$ \\
7 & 4.75 & 0.00 & 0.90 & 0.32 & - \\
8 & 2.36 & 0.00 & 0.00 & 0.00 & - \\
\hline
\end{tabular}

TABLE 5: Mix proportion of geopolymer concrete per cubic meter.

\begin{tabular}{lccccc}
\hline $\begin{array}{l}\text { Fly } \\
\text { ash }\end{array}$ & $\mathrm{NaOH}$ & $\mathrm{Na}_{2} \mathrm{SiO}_{3}$ & FA & $\mathrm{CA}$ & $\begin{array}{c}\text { Extra } \\
\text { water }\end{array}$ \\
\hline 300 & 52.5 & 52.5 & 722.24 & 1341.30 & 61.46 \\
1 & 0.175 & 0.175 & 2.40 & 4.4771 & 0.20 \\
\hline
\end{tabular}

TABLE 6: Quantity of fibres for various mixes.

\begin{tabular}{lcccccc}
\hline Steel fibre $(\%)$ & 0.0 & 0.1 & 0.2 & 0.3 & 0.4 & 0.5 \\
\hline Fibre quantity $\left(\mathrm{kg} / \mathrm{m}^{3}\right)$ & 0.0 & 2.53 & 5.06 & 7.59 & 10.12 & 12.65 \\
\hline
\end{tabular}

\section{Test Results}

The workability of fresh geopolymer concrete is measured by flow table apparatus as per IS: 1199-1959. After making the homogeneous mix, concrete was placed in two layers; each layer should be compacted 20 times with the tamping rod and then level the top surface. Lift the mould away from the concrete one minute after completing the mixing operation. Then apply fifteen jolting and measure the average diameter of subside concrete at minimum six equal intervals expressed as a percentage of the original base diameter. Examination of Table 7 indicates that the workability of geopolymer concrete including steel fibre reduces with increases in fibre content. It might be due to viscous nature of geopolymer concrete and uneven distribution of fibres in the mix. The maximum decrease in flow is $22.72 \%$ at $0.5 \%$ of fibre content. Wet and dry densities were recorded throughout the experimental program and the average values for densities are listed for various volume fractions of fibres. Table 7 shows that inclusion of fibres increases the density of concrete due to good particle packing and reduction in air content. The maximum increase in wet density is $2.98 \%$, whereas it is $3.13 \%$ in case of dry density.

3.1. Discussion on Mechanical Properties. The tests on hardened geopolymer concrete composites are carried out according to the relevant standards wherever applicable. New expressions for mechanical properties of GPCC are proposed in this investigation. Comparison of various strengths obtained using experimental work is presented in Table 8.
Compressive strength is determined by carrying out compressive strength test on cubes of sizes $150 \mathrm{~mm} \times 150 \mathrm{~mm} \times$ $150 \mathrm{~mm}$. The compressive strength of specimen is calculated by

$$
f_{\text {cu }}=\frac{P_{c}}{A} .
$$

The compressive strength of concrete increases with respect to fibre content up to $0.2 \%$ and then it decreases because higher percentage of fibre content reduces the workability of GPCC. The maximum increase in compressive strength of GPCC is $29.98 \%$ over that of normal geopolymer concrete. Expression for compressive strength in the third degree polynomial in terms of $V_{f}$ is given by the following equation:

$$
f_{\mathrm{cu}}=371.48 V_{f}^{3}-361.58 V_{f}^{2}+96.695 V_{f}+28.593 .
$$

Flexural test is carried out on beams of size $100 \mathrm{~mm} \times$ $100 \mathrm{~mm} \times 500 \mathrm{~mm}$ with two-point loads applied at the middle third of the span. The flexural strength is obtained by using

$$
f_{\text {cr }}=\frac{P L}{b d^{2}} \text {. }
$$

From Table 8 , it is observed that the maximum increase in flexural strength is $30.0 \%$ with $0.2 \%$ of fibre content over that of normal geopolymer concrete. Expression for flexural strength in the third degree polynomial in terms of $V_{f}$ is given by the following equation:

$$
f_{\text {cr }}=26.204 V_{f}^{3}-31.742 V_{f}^{2}+9.5717 V_{f}+3.1575 .
$$

Cylinders of size $100 \mathrm{~mm}$ diameter and $300 \mathrm{~mm}$ length are used to obtain split-tensile strength. The split-tensile strength is obtained by using

$$
f_{\mathrm{cr}}=\frac{2 P}{\pi d L} .
$$

The maximum increase in split-tensile strength is $30.05 \%$ with $0.2 \%$ of fibre content over that of normal geopolymer concrete. Expression for split-tensile strength in the third degree polynomial in terms of $V_{f}$ is given by the following equation:

$$
f_{\text {cys }}=28.056 V_{f}^{3}-33.702 V_{f}^{2}+10.1117 V_{f}+3.316 .
$$


TABLE 7: Workability, wet density, and dry density of GPCC Mixes.

\begin{tabular}{|c|c|c|c|c|c|c|c|}
\hline \multirow{2}{*}{$V_{f}(\%)$} & \multirow{2}{*}{ Flow $(\mathrm{mm})$} & \multirow{2}{*}{ Decrease in flow (\%) } & \multirow{2}{*}{ Degree of workability } & \multicolumn{2}{|c|}{ Density $\left(\mathrm{kg} / \mathrm{m}^{3}\right)$} & \multicolumn{2}{|c|}{ Increase in density (\%) } \\
\hline & & & & Wet & Dry & Wet & Dry \\
\hline 0.0 & 62.93 & 0.00 & High & 2583 & 2453 & 0.0 & 0.0 \\
\hline 0.1 & 60.40 & 4.02 & High & 2592 & 2460 & 0.34 & 0.28 \\
\hline 0.2 & 57.33 & 8.89 & High & 2616 & 2479 & 1.27 & 1.05 \\
\hline 0.3 & 54.13 & 13.98 & High & 2634 & 2505 & 1.97 & 2.11 \\
\hline 0.4 & 51.73 & 17.79 & High & 2641 & 2515 & 2.24 & 2.52 \\
\hline 0.5 & 48.40 & 22.72 & Medium & 2660 & 2530 & 2.98 & 3.13 \\
\hline
\end{tabular}

TABLE 8: Comparison of compressive strength $\left(f_{\text {cu }}\right)$, flexural strength $\left(f_{\text {cr }}\right)$, split-tensile strength $\left(f_{\text {cys }}\right)$, and bond strength $\left(f_{\text {bd }}\right)$ for various percentages of steel fibres $\left(V_{f}\right)$.

\begin{tabular}{ccccccccc}
\hline \multirow{2}{*}{$V_{f}$} & \multicolumn{3}{c}{ Strengths $(\mathrm{MPa})$} & \multicolumn{4}{c}{ Percentage increase in strength } \\
& $f_{\mathrm{cu}}$ & $f_{\mathrm{cr}}$ & $f_{\mathrm{cys}}$ & $f_{\mathrm{bd}}$ & $f_{\mathrm{cu}}$ & $f_{\text {cr }}$ & $f_{\mathrm{cys}}$ \\
\hline 0.0 & 28.89 & 3.20 & 3.36 & 12.10 & 0.00 & 0.00 & 0.00 & 0.00 \\
0.1 & 33.55 & 3.68 & 3.87 & 12.82 & 16.13 & 15.00 & 15.17 & 5.95 \\
0.2 & 37.55 & 4.16 & 4.37 & 14.05 & 29.98 & 30.00 & 30.05 & 16.11 \\
0.3 & 33.11 & 3.87 & 4.06 & 13.59 & 14.61 & 20.90 & 20.83 & 12.31 \\
0.4 & 32.22 & 3.52 & 3.70 & 13.33 & 11.53 & 10.00 & 10.11 & 10.16 \\
0.5 & 31.5 & 3.31 & 3.48 & 12.94 & 9.03 & 3.43 & 3.57 \\
\hline
\end{tabular}

The bond strength test was carried out according to IS 2770 [21]. A $16 \mathrm{~mm}$ diameter deformed steel reinforcing bar was embedded into the concrete cube at centre up to depth of $150 \mathrm{~mm}$. The total length of bar is $600 \mathrm{~mm}$. All specimens are tested up to failure of bar matrix interfacial bond. The peak load at failure of bond and maximum slip is observed. All specimens failed with vertical crack along the embedded length of bar with cracking sound. The maximum increase in strength is $16.11 \%$ with $0.2 \%$ of fibre content over that of normal geopolymer concrete. The bond strength has been computed from the following expression:

$$
f_{\mathrm{bd}}=\frac{P}{\pi D L} .
$$

Expression for bond strength in the third degree polynomial in terms of $V_{f}$ is given by the following equation:

$$
f_{\mathrm{bd}}=22.87 V_{f}^{3}-37.706 V_{f}^{2}+14.91 V_{f}+12.008 .
$$

Optimum fibre content for various strengths of geopolymer concrete is presented in Table 9. Figures 1, 2, 3, and 4 show the variation of various strengths of geopolymer concrete composites with the percentage of steel fibres. The comparison of various strengths of geopolymer concrete composites obtained using proposed empirical formulas is presented in Table 10.

3.2. Elastic Properties. Elastic properties such as modulus of elasticity, modulus of rigidity, and Poisson's ratio are the important parameters in the analysis of structures. These properties are obtained by various methods available in the literature.
TABLE 9: Optimum fibre content and maximum percentage increase in various strengths.

\begin{tabular}{lccc}
\hline Strength & $V_{f}$ & $\begin{array}{c}\text { Maximum } \\
\text { strength (MPa) }\end{array}$ & $\begin{array}{c}\text { Percentage increase in } \\
\text { strength (\%) }\end{array}$ \\
\hline$f_{\text {cu }}$ & 0.2 & 37.55 & 29.98 \\
$f_{\text {cr }}$ & 0.2 & 4.16 & 30.00 \\
$f_{\text {cys }}$ & 0.2 & 4.37 & 30.35 \\
$f_{\text {bd }}$ & 0.2 & 14.05 & 16.11 \\
\hline
\end{tabular}

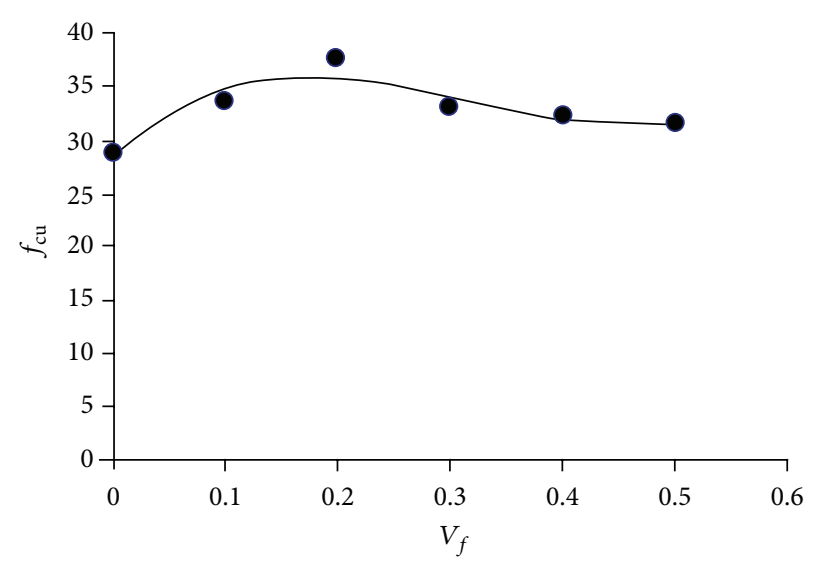

FIGURE 1: Variation of compressive strength $\left(f_{\mathrm{cu}}\right)$ with respect to percentage of steel fibres $\left(V_{f}\right)$.

3.2.1. Modulus of Elasticity. The modulus of elasticity is obtained by various methods available in the literature as given below. 
TABLE 10: Compressive strength $\left(f_{\text {cu }}\right)$, flexural strength $\left(f_{\text {cr }}\right)$, split-tensile strength $\left(f_{\text {cys }}\right)$, and bond strength $\left(f_{\text {bd }}\right)$ for various percentage of steel fibre $\left(V_{f}\right)$ obtained using proposed equations.

\begin{tabular}{cccccccccc}
\hline$V_{f}$ & \multicolumn{3}{c}{ Strength $(\mathrm{MPa})$} & \multicolumn{4}{c}{ Percentage increase } \\
& $\begin{array}{c}f_{\text {cu }} \\
\text { Equation (2) }\end{array}$ & $\begin{array}{c}f_{\text {cr }} \\
\text { Equation (4) }\end{array}$ & $\begin{array}{c}f_{\text {cys }} \\
\text { Equation (6) }\end{array}$ & $\begin{array}{c}f_{\text {bd }} \\
\text { Equation }(8)\end{array}$ & $f_{\text {cu }}$ & $f_{\text {cr }}$ & $f_{\text {cys }}$ & $f_{\text {bd }}$ \\
\hline 0.0 & 28.59 & 3.15 & 3.32 & 12.00 & 0.00 & 0.00 & 0.00 & 0.00 \\
0.1 & 34.71 & 3.82 & 4.01 & 13.14 & 20.35 & 21.26 & 20.78 & 9.50 \\
0.2 & 35.83 & 4.01 & 4.21 & 13.66 & 25.32 & 27.30 & 26.80 & 13.83 \\
0.3 & 34.18 & 3.87 & 4.07 & 13.70 & 19.55 & 22.85 & 22.59 & 14.16 \\
0.4 & 31.98 & 3.58 & 3.76 & 13.40 & 11.85 & 13.65 & 13.25 & 11.66 \\
0.5 & 31.47 & 3.32 & 3.45 & 12.98 & 10.07 & 5.39 & 3.91 & 8.16 \\
\hline
\end{tabular}

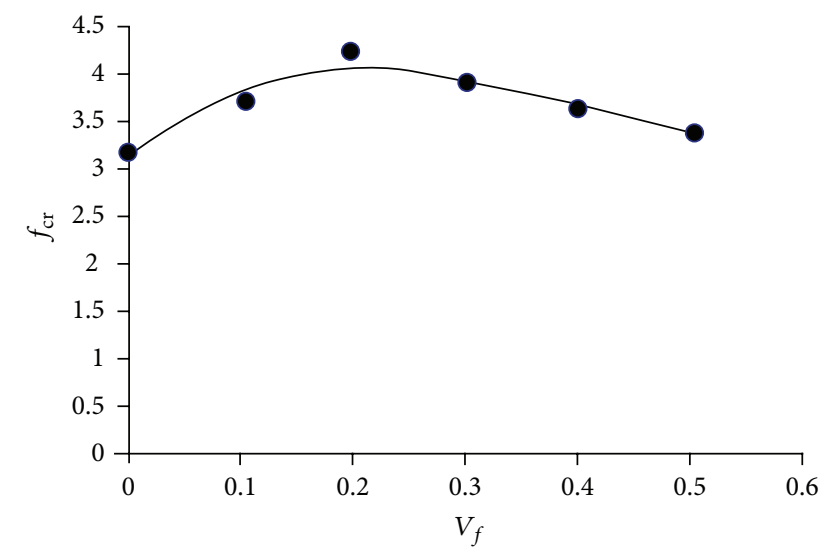

FIGURE 2: Variation of flexural strength $\left(f_{\text {cr }}\right)$ with respect to percentage of steel fibres $\left(V_{f}\right)$.

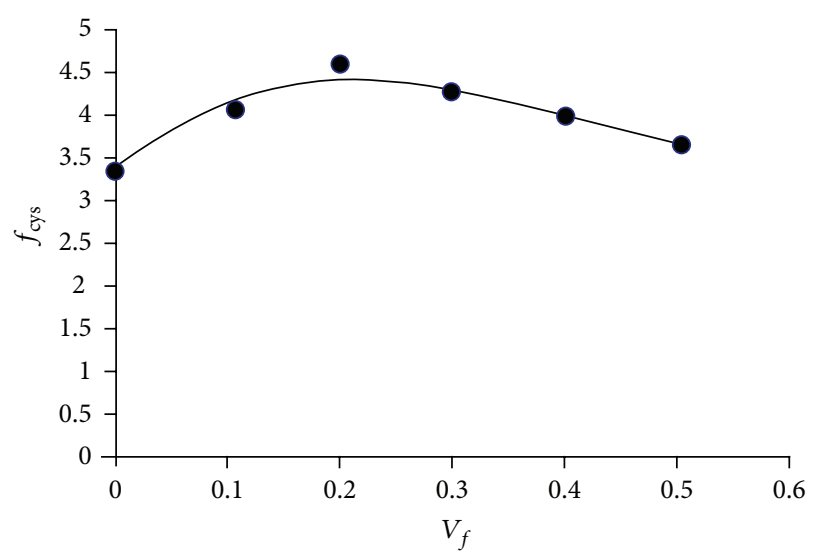

FIGURE 3: Variation of split-tensile strength $\left(f_{\text {cys }}\right)$ with respect to percentage of steel fibres $\left(V_{f}\right)$. as

As per IS: 456 [22], the modulus of elasticity is calculated

$$
E_{\mathrm{fc}}=5 \sqrt{f_{\mathrm{cu}}}
$$

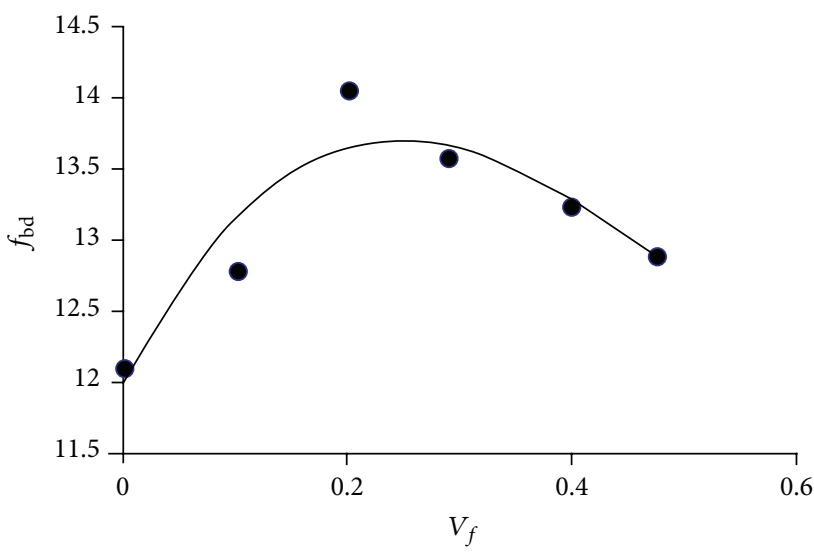

FIGURE 4: Variation of bond strength $\left(f_{\text {bd }}\right)$ with respect to percentage of steel fibres $\left(V_{f}\right)$.

Modulus of elasticity of fibre reinforced composites can be calculated using law of mixtures as suggested by Hannant [23] and Tan et al. [24] as

$$
E_{\mathrm{fc}}=\left(1-\eta_{1} \eta_{2} V_{f}\right) E_{m}+\eta_{1} \eta_{2} V_{f} E_{f}
$$

where

$$
\begin{aligned}
& \eta_{1}=\text { fibre orientation factor }(1 / 6) \\
& \eta_{2}=\text { efficiency factors }(1 / 3) \\
& V_{f}=\text { fibre content }(\%) \\
& E_{m}=\text { modulus of elasticity of matrix }(\mathrm{GPa})=5 \sqrt{f_{\mathrm{cu}}} \\
& E_{f}=\text { modulus of elasticity of fibre }(\mathrm{GPa})=210
\end{aligned}
$$

The equation of modulus of elasticity in terms of compressive strength $\left(f_{\mathrm{cu}}\right)$ and specific gravity $(\gamma)$ is also given by Kakizaki et al. [25] as

$$
E_{\mathrm{fc}}=0.8 \times 10^{5}\left(\frac{\gamma}{2.3}\right)^{1.5} \sqrt{\frac{f_{\mathrm{cu}}}{350}},
$$

where $\gamma=$ specific gravity of concrete (dry density of composite/1000). 
TABLE 11: Elastic properties of geopolymer concrete composites (GPCC).

\begin{tabular}{cccccc}
\hline$V_{f}$ & & \multicolumn{2}{c}{ Modulus of elasticity $\left(E_{\mathrm{fc}}\right)$} & \multicolumn{2}{c}{$\begin{array}{c}\text { Poisson's ratio }(\mu) \\
\text { Equation }(20)\end{array}$} \\
\hline 0.0 & Equation (9) & Equation (10) & Equation (11) & Equation (12) & 0.1107 \\
0.1 & 26.874 & 36.931 & 26.516 & 26.046 & 28.069 \\
0.2 & 28.96 & 27.881 & 28.455 & 29.690 & 0.1096 \\
0.3 & 30.63 & 32.603 & 29.300 & 27.884 & 0.1107 \\
0.4 & 28.77 & 31.76 & 30.46 & 30.050 & 0.1168 \\
0.5 & 28.38 & 32.37 & 27.986 & 27.198 & 0.1092 \\
\hline
\end{tabular}

TABLE 12: Modulus of elasticity and shear modulus using Halpin Tsai equations [1].

\begin{tabular}{|c|c|c|c|c|c|c|c|}
\hline$V_{f}$ & $\begin{array}{c}\eta_{L} \\
\text { Equation (15) }\end{array}$ & $\begin{array}{c}\eta_{T} \\
\text { Equation (16) }\end{array}$ & $\begin{array}{c}E_{L}(\mathrm{GPa}) \\
\text { Equation (13) }\end{array}$ & $\begin{array}{c}E_{T}(\mathrm{GPa}) \\
\text { Equation (14) }\end{array}$ & $\begin{array}{c}E_{R}(\mathrm{GPa}) \\
\text { Equation (17) }\end{array}$ & $\begin{array}{c}G_{R}(\mathrm{GPa}) \\
\text { Equation }(18)\end{array}$ & $\begin{array}{c}E_{\mathrm{fc}}(\mathrm{GPa}) \\
\text { Equation (19) }\end{array}$ \\
\hline 0.0 & 0.063 & 0.694 & 26.87 & 26.87 & 26.87 & 10.07 & 26.874 \\
\hline 0.1 & 0.058 & 0.675 & 46.02 & 35.24 & 93.28 & 14.56 & 35.353 \\
\hline 0.2 & 0.054 & 0.661 & 64.40 & 44.63 & 52.04 & 19.21 & 41.632 \\
\hline 0.3 & 0.058 & 0.678 & 80.22 & 50.81 & 61.84 & 22.73 & 43.286 \\
\hline 0.4 & 0.059 & 0.681 & 97.66 & 60.25 & 74.28 & 27.27 & 44.568 \\
\hline 0.5 & 0.060 & 0.683 & 115.71 & 71.70 & 88.21 & 32.39 & 44.106 \\
\hline
\end{tabular}

For average value of specific gravity, (11) leads to the following form:

$$
E_{\mathrm{fc}}=4846 \sqrt{f_{\mathrm{cu}}}
$$

The modulus of elasticity obtained by using (9) through (12) is shown in Table 11. Halpin Tsai equations [1] based on micromechanics analysis can also be used to predict the elastic constants of fibre composites. The longitudinal $\left(E_{L}\right)$ and transverse moduli $\left(E_{T}\right)$ can be evaluated using following equations:

$$
\begin{aligned}
& E_{L}=E_{m} \frac{1+\left(2 \lambda \eta_{L} V_{f}\right)}{1-\eta_{L} V_{f}}, \\
& E_{T}=E_{m} \frac{1+\left(2 \eta_{T} V_{f}\right)}{1-\eta_{T} V_{f}},
\end{aligned}
$$

where

$$
\begin{gathered}
\eta_{L}=\frac{\left(E_{f} / E_{m}\right)-1}{\left(E_{f} / E_{m}\right)+2 \lambda} \\
\eta_{T}=\frac{\left(E_{f} / E_{m}\right)-1}{\left(E_{f} / E_{m}\right)+2}
\end{gathered}
$$

where $\lambda$ is the aspect ratio of fibre $\left(L_{f} / h_{f}\right)$ where $L_{f}$ is the length of fibre and $h_{f}$ is the thickness of fibre. Modulus of elasticity and shear modulus of randomly oriented fibre reinforced concrete can be predicted using the following relations:

$$
\begin{aligned}
& E_{R}=\frac{1}{8}\left(3 E_{L}+5 E_{T}\right), \\
& G_{R}=\frac{1}{8}\left(E_{L}+2 E_{T}\right),
\end{aligned}
$$

where $E_{L}$ and $E_{T}$ are, respectively, the longitudinal and transverse moduli of fibre composite having the same fibre aspect ratio and fibre volume fraction. The results obtained using (17) are modified according to (19) to have the similar trend with the other results and are presented in Table 12:

$$
E_{\mathrm{fc}}=\left(1-V_{f}\right) E_{R}
$$

The behavior of geopolymer concrete is very complex. So, the modulus of elasticity calculated by various methods does not match with each other. But it is observed that the modulus of elasticity increases with incorporation of steel fibres up to $0.2 \%$ by volume and then decreases with increase in fibre content but higher than plain geopolymer concrete. This means that fibre improves the elastic behavior of geopolymer concrete which is more brittle than cement concrete.

3.2.2. Poisson's Ratio. The Poisson's ratio $(\mu)$ is determined according to Ghugal [26] using strength of material theory based on flexural strength and compressive strength and is given by the following relation:

$$
\mu=\frac{f_{\mathrm{cr}}}{f_{\mathrm{cu}}} .
$$

Table 11 shows the effect of steel fibers on Poisson's ratio of GPCC. 


\section{Conclusions}

Geopolymer concrete is a new invention in the world of concrete in which cement is totally replaced by industrial waste which contributes towards the global worming by reducing use of cement and utilisation of byproducts like fly ash. Since geopolymer concrete is more brittle than conventional concrete, steel fibres are used to make it an elastic one.

This paper presents the effect of steel fibres on mechanical and elastic properties of geopolymer concrete. From the experimental results it is concluded that the wet and dry densities of geopolymer concrete composites increased continuously with increase in fibre content, whereas the workability of geopolymer concrete composites reduced with increase in fibre content. Optimum fibre content for the maximum value of various strengths of geopolymer concrete composites is $0.2 \%$. The maximum percentage increase in compressive strength, flexural strength, split tensile strength, and bond strength is $29.98 \%, 30 \%, 30.05 \%$, and $16.11 \%$, respectively. The proposed equation for modulus of elasticity yield excellent result and Poisson's ratio varies between specified limit.

\section{Conflict of Interests}

The authors declare that there is no conflict of interests regarding the publication of this paper.

\section{Acknowledgments}

The support from Saurabh Shah, Sanket Sakalkar, Amol Gite, Ritesh Gajare and Chetan Shahare, Graduate students, Department of Civil Engineering, SRES's College of Engineering, Kopargaon, Maharashtra, India, for this study is gratefully acknowledged.

\section{References}

[1] J. C. Halpin and S. W. Tsai, "Effects of environmental factors on composite materials," Tech. Rep. AFML-TR, 1969.

[2] J. Davidovits, "Geopolymers-inorganic polymeric new materials," Journal of Thermal Analysis, vol. 37, no. 8, pp. 1633-1656, 1991.

[3] J. Davidovits, "Geopolymers: man-made geosynthesis and the resulting development of very early high strength cement," Journal of Material Education, vol. 16, no. 2, pp. 91-139, 1994.

[4] D. Hardjito, S. E. Wallah, D. M. J. Sumajouw, and B. V. Rangan, "On the development of fly ash-based geopolymer concrete," ACI Materials Journal, vol. 101, no. 6, pp. 467-472, 2004.

[5] P. Chindaprasirt, T. Chareerat, and V. Sirivivatnanon, "Workability and strength of coarse high calcium fly ash geopolymer," Cement and Concrete Composites, vol. 29, no. 3, pp. 224-229, 2007.

[6] B. V. Rangan, "Mix design and production of flyash based geopolymer concrete," Indian Concrete Journal, vol. 82, no. 5, pp. 7-15, 2008.

[7] R. Anuradha, V. Sreevidya, R. Venkatasubramani, and B. V. Rangan, "Modified guidelines for geopolymer concrete mix design using Indian standards," Asian Journal of Civil Engineering, vol. 8, pp. 353-369, 2012.
[8] S. V. Patankar, S. S. Jamkar, and Y. M. Ghugal, "Effect of sodium hydroxide an flow and strength of fly ash based geopolymer mortar," Journal of Structural Engineering, vol. 39, no. 1, pp. 7-12, 2012.

[9] J. G. S. Van Jaarsveld, J. S. J. Van Deventer, and L. Lorenzen, “The potential use of geopolymeric materials to immobilise toxic metals-part I: theory and applications," Minerals Engineering, vol. 10, no. 7, pp. 659-669, 1997.

[10] K. A. Anuar, A. R. M. Ridzuanand, and S. Ismail, "Strength characteristic of gpc containing recycled concrete aggregate," International Journal of Civil and Environmental Engineering, vol. 11, no. 1, pp. 81-85, 2011.

[11] S. Alonso and A. Palomo, "Alkaline activation of metakaolin and calcium hydroxide mixtures: influence of temperature, activator concentration and solids ratio," Materials Letters, vol. 47, no. 1-2, pp. 55-62, 2001.

[12] D. M. J. Sumajouw, D. Hardjito, S. E. Wallah, and B. V. Rangan, "Fly ash-based geopolymer concrete: study of slender reinforced columns," Journal of Materials Science, vol. 42, no. 9, pp. 3124-3130, 2007.

[13] T. Bakharev, "Resistance of geopolymer materials to acid attack," Cement and Concrete Research, vol. 35, no. 4, pp. 658-670, 2005.

[14] D. Pernica, P. N. B. Reis, J. A. M. Ferreira, and P. Louda, “Effect of test conditions on the bending strength of a geopolymerreinforced composite," Journal of Materials Science, vol. 45, no. 3, pp. 744-749, 2010.

[15] K. Vijai, R. Kumutha, and B. G. Vishnuram, "Properties of glass fibre reinforced geopolymer concrete composite," Asian Journal of Civil Engineering, vol. 13, no. 4, pp. 511-520, 2012.

[16] K. Vijai, R. Kumutha, and B. G. Vishnuram, "Effect of inclusion of steel fibres on the properties of geopolymer concrete composites," Asian Journal of Civil Engineering, vol. 13, no. 3, pp. 377385,2012

[17] K. Vijai, R. Kumutha, and B. G. Vishnuram, "Experimental investigations on mechanical properties of geopolymer concrete composites," Asian Journal of Civil Engineering, vol. 13, no. 1, pp. 89-96, 2012.

[18] V. Sathish Kumar, B. S. Thomas, and A. Chtistopher, "An environmental study on the properties of glass fibre reinforced geopolymer concrete," International Journal of Engineering Research and Applications, vol. 2, no. 6, pp. 722-726, 2012.

[19] A. Bhowmick and S. Ghosh, "Effect of synthesizing parameters on workability and compressive strength of fly ash based geopolymer mortar," International Journal of Civil and Structural Engineering, vol. 3, no. 2, pp. 168-177, 2012.

[20] Y. M. Ghugal and S. A. Bhalchandra, "Performance of fibre reinforced high strength silica fume concrete," Civil Engineering and Construction Review, vol. 22, pp. 32-44, 2009.

[21] IS 2770, Methods of Testing Bond Strength in Reinforced Concrete- Part I, Bureau of Indian Standards, New Delhi, India, 1997.

[22] IS 456, Code of Practice for Plain and Reinforced Concrete, Bureau of Indian Standards, New Delhi, India, 2000.

[23] D. J. Hannant, Fibre Cements and Fibre Concretes, John Wiley and Sons, New York, NY, USA, 1978.

[24] K. H. Tan, P. Paramasivam, and K. C. Tan, "Instantaneous and long-term deflections of steel fiber reinforced concrete beams," ACI Structural Journal, vol. 91, no. 4, pp. 384-393, 1994. 
[25] M. Kakizaki, M. Harada, T. Soshiroda, S. Kubota, T. Ikeda, and Y. Kasai, "Strength and elastic modulus of recycled agreegate concrete," in Proceedings of the 2nd International RILEM Synposium on Reuse of Demolition Waste, vol. 2, pp. 565-574, 1988.

[26] Y. M. Ghugal, "Effects of steel fibres on various strengths of concrete," Indian Concrete Journal, vol. 4, no. 3, pp. 23-29, 2003. 

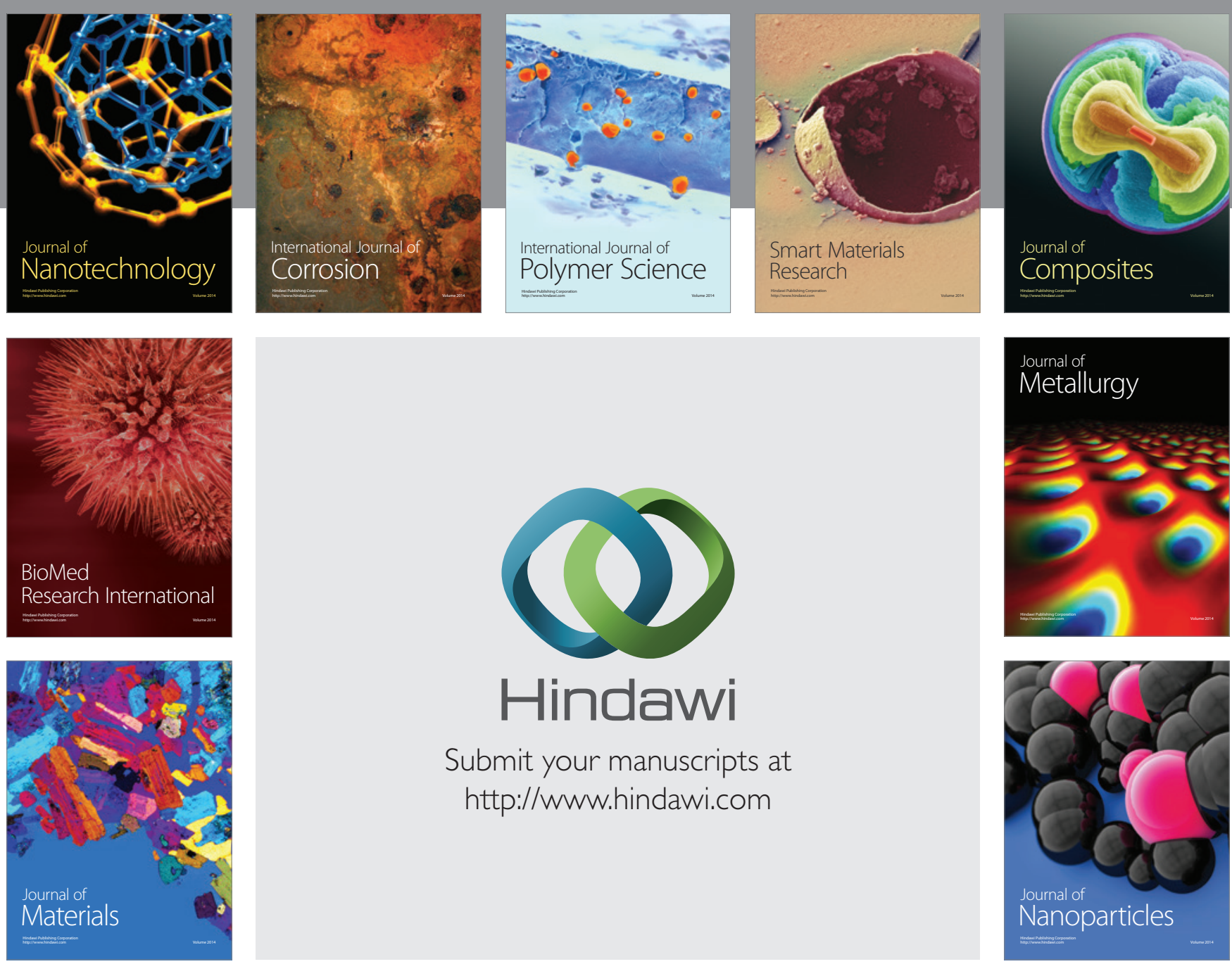

Submit your manuscripts at http://www.hindawi.com
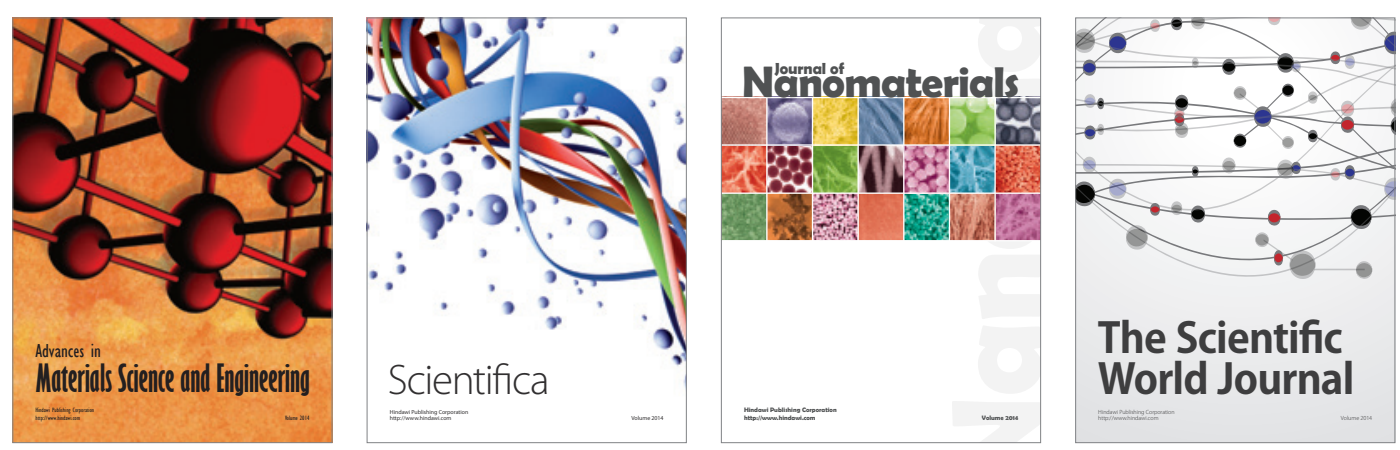

\section{The Scientific World Journal}
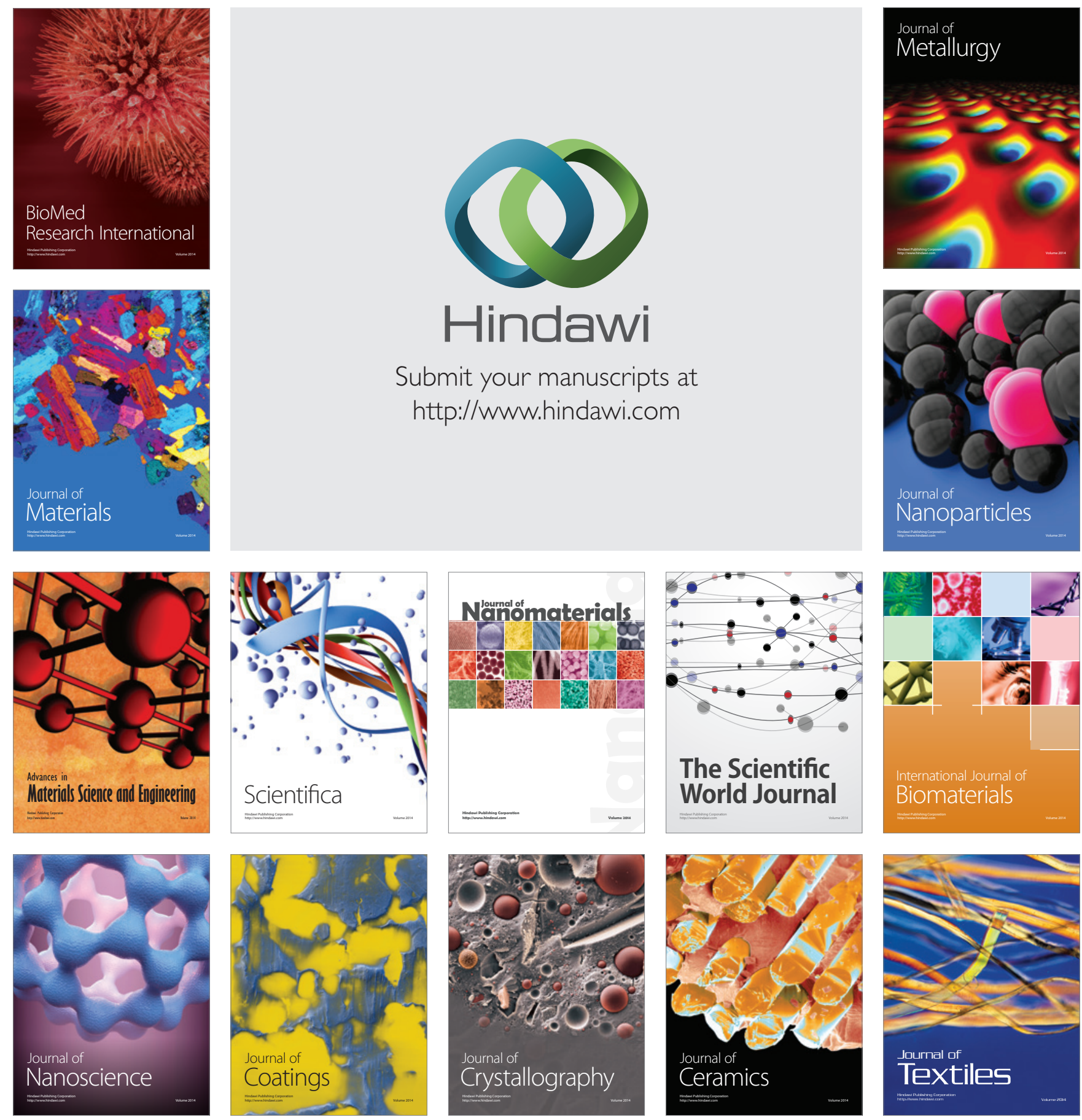